\title{
THE STATE OF MOLDAVIAN VIPER (VIPERA URSINII MOLDAVICA) IN THE CONTEXT OF THE ACTION PLAN FOR THEIR CONSERVATION (ANNEXED TO THE BERN CONVENTION)
}

\author{
Vladimir Țurcan \\ Institut of Zoology, Chişinău, Republic of Moldova, e-mail:vladimirtsurcan@mail.ru
}

\begin{abstract}
Based on the generalization of data from previous publications and own results, regarding the distribution of Meadow Viper (Vipera ursini) in the Dniester - Prut interfluve, the current species state in the context of the Action Plan for conservation, annexed to the Bern Convention, is characterized. The need to complex study of local habitat status and to take measures for their conservation is discussed. The influence of some anthropogenic and climatic factors upon the habitats and the problems of their conservation in the current conditions of agrolandscape are analyzed.
\end{abstract}

\section{Introduction}

The meadow viper, Vipera ursinii, has a relict, post-glacial distribution and occurs as a series of isolated populations in limited areas of southern and central Europe. Five currently described subspecies (Vipera ursinii ursinii, Vipera u. macrops, Vipera u.graeca, Vipera u.rakosiensis, Vipera $u$. moldavica) are in severe decline. This species is now considered by herpetologists to be one of the most endangered snakes in Europe. Hungarian (Vipera u.rakosiensis) and Moldavian (Vipera $u$. moldavica) meadow vipers are now on the verge of extinction and, with only 13 and 4 known populations respectively, are amongst the most endangered of all vertebrate taxa in the European area. Therefore these species have been included in the conservation action plan. Species Action Plan has been commissioned by the Standing Committee of the Bern Convention in order to assess the extent of the problems faced by the meadow viper in Europe and to make appropriate recommendations for specific actions to address these problems. Taking into account the Moldova's commitments to the Berne Convention we mention that the study on situation of this species is quite actual and necessary. The originality of the data consists in the revision of the populations described about 50 years ago.

\section{Material and methods}

The paper presents the results of multiannual estimates made during field research on the spread of steppe viper in the Prut-Dniester area. Estimates were made by the route method during periods of maximum activity of the reptiles. The information obtained as a result of personal communications with the local population was also taken into account. As a result of the comparative analysis of the multiannual data obtained during this period and those of the publications of the previous authors, changes were identified, which took place in the herpetofaunistic complex of the last decades. The character of these changes was examined in faunal and archaeological aspect. 


\section{Rezults and discussion}

The subspecies Vipera ursini moldavica was described [2] based on specimens collected from the right bank of the Prut river (Valea lui David, Iaşi County). The phylogenetic analysis of the representatives from different parts of the area showed that the specimens are distinguished by some morphological and genetic features, which allowed the authors to describe them as a separate subspecies and a population that has been genetically isolated for a long time in the region between the Carpathians and the Prut. On the right bank of Prut river several more local populations of this subspecies have been recorded, but they are on the verge of extinction and require urgent conservation measures $[1,3]$.

The existence of steppe viper populations in the Republic of Moldova described in the 1970's of the XX century [5] until now has not been confirmed, but the presence of the species is possible on some steppe sectors, which have been preserved in the Middle Prut Plain. This assumption is based on the fact that in 2003 a population of blotched snake (Elaphe sauromates, Palass 1814) was discovered here, which was also preserved in the landscape resrve "Suta de Movile" and the natural reserve "Pădurea Domnească" [9].

Possibly, this population is a "relict" from the former rich herpetofauna that once existed in the Bălţi steppe. It is isolated from the populations of southern Moldova at a distance of 300 $\mathrm{km}$ and represents the northern limit of the species area. Also, in the left Prut river basin (steppe area of Bălţi and Făleşti) there are many steppe sectors identical in terms of natural appearance and the degree of anthropogenic impact with those on the right Prut basin, populated by vipers. This fact increases the probability of the existence of V.ursinii moldavica in the Dniester-Prut interfluve.

The results of the study of the current spread of amphibian and reptile species in the Dniester-Prut interfluve show that the historical formation of the herpetofaunistic complex was determined by the landscape differentiation of this geographical area. The steppe areas of Balti and Bugeac are separated by the central forest area „Codrii”, which is in fact an extension of the Central Moldavian Plateau. This differentiation largely determined the specific composition and spatial distribution of the species $[7,8]$. The formation of the serpent fauna took place both on account of the forest forms (E. longissima, C. austriaca, $V$. berus) coming from the Carpathians, and of the steppe ones (C. jugularis, E. sauromates, V. ursini), which have spread from the Ponto-Caspian region, entering the Plain of the Middle Prut through its corridors and possibly through the corridors of Răut.

Being historically isolated in the Prut Plain, the populations of these species probably differ genetically, which allows us to consider the existence of the subspecies V.u.moldavica possible as well in the Republic of Moldova. 


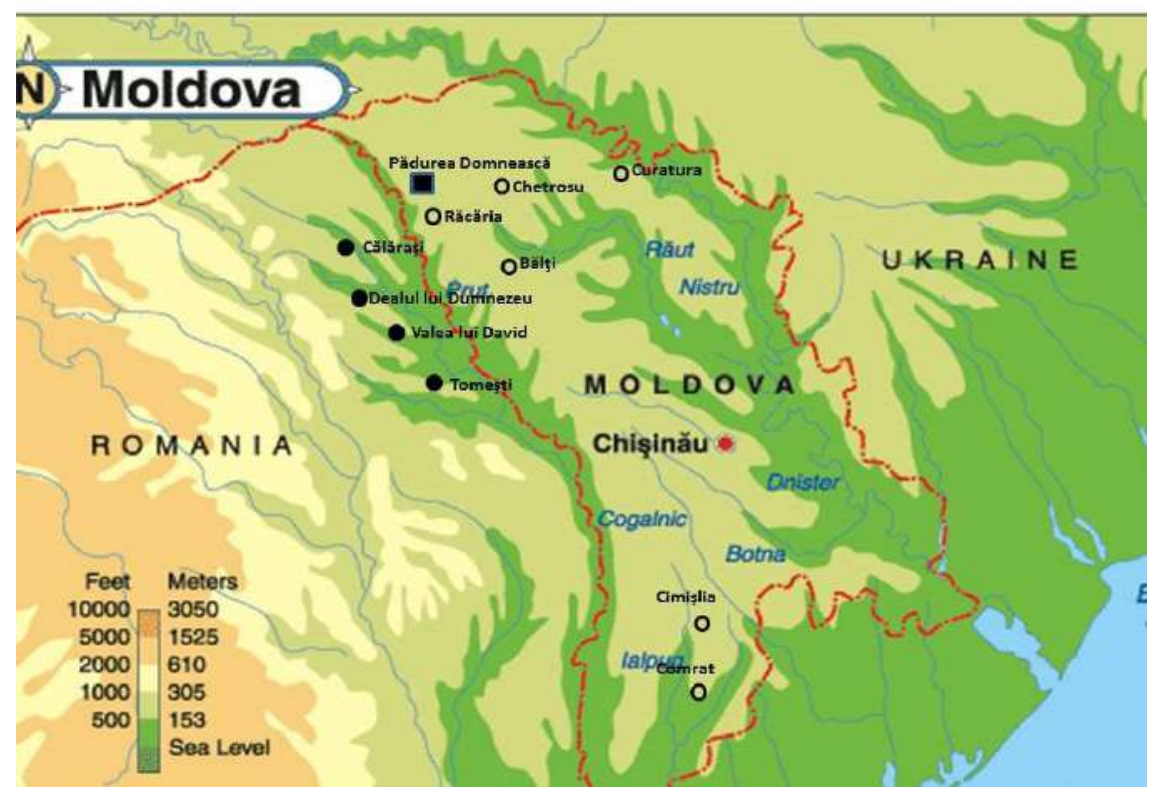

Figure 1 The populations of $V$. ursini described in the 1970 by Tofan (empty circle), those of existing V.u.moldavica (black circle) and E. sauromates (black square).

In Moldova, the steppe viper is considered an endangered species. The last data that confirm its existence refer to the population near Ciucur-Mingir locality from Cimişlia district (1970). Until 1960-70 it was considered a widespread species [6]. In other source information of 11 specimens collected in Moldova can be found [4]. These data show that in the last century the steppe viper was widespread in the Prut-Dniester area. Its area occupies the southern steppe area and the Bălţi steppe in the north of the country isolated from the Codri Plateau.

In the last 10-15 years, during field studies conducted in various ecosystems, including the steppe areas, the species was not found (but there were no special projects to search and assess the state of this species). Taking into account that in Moldova the local populations of some rare species (for example, E. sauromates) are still preserved in small areas, as well as the presence of steppe viper in the Middle Prut Plain in Romania, we assume that $V$. ursinii could have survived on the Dniester-Prut area as small populations. This requires special field research aimed at finding this particular species. In Bulgaria, where this species was considered extinct, it was recently found.

The decline of the species was determined by the drastic reduction of natural steppes by about $90 \%$. The steppe areas of Balti and Bugeac almost entirely have been transformed into agricultural fields and the remaining sectors are small, isolated and have a degraded appearance due to excessive grazing.

In the point 2.7 of the Action Plan for the Conservation of the Meadow Viper (Vipera ursinii) in Europe it is indicated that research has been carried out in the Republic of Moldova on the spread of steppe vipers. However, it is necessary to mention that until the last years, not enough data have been accumulated to confirm the extinction of the species. Special field stud- 
ies was conducted (Korsos Z., Ujvari B, Tsurcan V.) but not all potential sectors were covered. In point 4.2.6. it is recommended to carry out urgent research in the Republic of Moldova regarding the subspecies $V$. u. moldavica. That is why it is necessary to carry out a project aimed at elucidating the current state and developing recommendations for the detection, protection and conservation of the subspecies in existing habitats. In case of identification of local populations, the measures and recommendations provided in p. 3.2 will be taken. In point 4.6.1. it is recommended to practice in particular for Hungary, Romania and the Republic of Moldova the captive reproduction and reintroduction in nature of the steppe viper. This method will be used to recover depressed populations and repopulate potential habitats, where this species was once widespread.

\section{Conclusions}

The existence of steppe viper populations in the Republic of Moldova described in the 1970 's of the XX century until now has not been confirmed, but the presence of the species is possible on some steppe sectors, which have been preserved in the Middle Prut Plain (landscape reserve "Suta de Movile" and natural reserve "Pădurea Domnească"), as well as in Bugeac steppe areas. Considering that in Moldova, the local populations of some rare species (for example, E. sauromates) are still preserved in small areas, as well as the steppe viper in the Middle Prut Plain in Romania, we assume that $V$. ursinii could have survived on the Dniester-Prut area as small population. The decline of the species was determined by the drastic reduction of natural steppes by about $90 \%$. The steppe areas of Balti and Bugeac, almost entirely, have been transformed into agricultural fields and the remaining sectors are small, isolated and have a degraded appearance due to excessive grazing. That is why it is necessary to carry out a project aimed at elucidating the current state and developing recommendations for the detection, protection and conservation of the subspecies in existing habitats.

The work was carried out within the State Program project 20.80009.7007.02

\section{Bibliography}

1. Krecsak L., Zamfirescu Ş., Korsos Z. An updated overview of the distribution of the Moldavian steppe viper (Vipera ursinii moldavica Nilson, Andren et Joger, 1993)

2. Nilson G., Andren C., Joger U. A re-evaluation of the taxonomic status of the Moldavian steppe viper based on immunological investigation, with a disscussion of the hypothesis of secondary integradation between V.u.racisiensis and V.u.renardi /Amphibia-Reptilia.- 1993. -14, pp. 4557.

3. Zamfirescu Ş., Zamfirescu O., Poipescu I. Research on the habitatas of Vipera ursini moldavica populations from Iaşi County. Analele Ştiinţifice ale Universităţii „Al. I. Cuza” Iaşi, s. Biologie animală, Tom LIII, 2007, p. 159-166.

4. Перевалов А.А. Адаптивные особенности содержания гемоглобина у змей. Мат. 1-й республ. Межвуз. Научно-практ. конференции. Кишинев, 1970, с. 147-149.

5.Тофан В.Е. экология обыкновенной и степной гадюк в Молдавии. Мат. Конф. По итогам научно-исслед. Работы за 1969г. Тираспольский пед.институт. Кишинев, 1972, с. 79-80 
6. Хозацкий Л.И., Тофан В.Е. Герпетологическое районирование Молдавии в историческом аспекте. В кн.: Актуальные вопр. Зоогеогр: Тез. Докл. Всесоюз. Зоогеогр. Конф., Кишинев, 1975, с. 242.

7. Цуркану В. Ф. Формирование и современное распространение фауны змей Прутского междуречья. Buletinul ştiinţific al Muzeului Naţional de Etnografie şi Istorie Naturală. 2005, Vol. 2 (15), p.73-77.

8. Цуркан В. Эколого-географический аспект распространения герпетофауны в Молдове. Академику Л.С.Бергу-135 лет. Бендеры, 2011, с. 383-389.

9. Цуркан В.Ф. Пространственно-таксономический аспект герпетофауны Молдовы. Геоэкологические и биоэкологические проблемы северного Приерноморья. Мат. V Международной научно-практичской конференции. Тирасполь, 2014, с. 307-311. 